\title{
Evaluation of the fibulin 5 gene polymorphism as a factor related to the occurrence of pelvic organ prolapse
}

\author{
(D) Marcus Vinicius Barbosa de Paula' \\ (D) Marcos Antônio de Farias Lira Júnior ${ }^{1}$ \\ (iD) Vivian Costa e Silva Crocco Monteiro ${ }^{2}$ \\ (iD) Ricardo Peres Souto ${ }^{3}$ \\ (1) César Eduardo Fernandes ${ }^{4}$ \\ (iD) Emerson de Oliveira ${ }^{5}$
}

\begin{abstract}
1. Mestrando, Departamento de Ginecologia e Obstetrícia, Faculdade de Medicina do ABC, Santo André, SP, Brasil. 2. Graduando, Departamento de Ginecologia e Obstetrícia, Faculdade de Medicina do ABC, Santo André, SP, Brasil. 3. Professor Assistente, Departamento de Morfologia e Psicologia, Faculdade de Medicina do ABC, Santo André, SP, Brasil. 4. Professor Titular, Departamento de Ginecologia e Obstetrícia, Faculdade de Medicina do ABC, Santo André, SP, Brasil. 5. Professor Assistente, Departamento de Ginecologia e Obstetrícia, Faculdade de medicina do ABC, Santo André,SP, Brasil.
\end{abstract}

\section{SUMMARY}

OBJECTIVE: Pelvic organ prolapse (POP) is a very frequent situation in our population that may lead to a significant decrease in patients' quality of life. Currently, we are looking for predictive factors for the development of POPs; thus, this study seeks to evaluate whether the Fibulin 5 polymorphism (FBLN5) is associated with the occurrence of POP.

METHODS: This is a cohort study with postmenopausal women who were divided into groups by POP stage: POP stages 0 and I (control group) and POP stages III and IV (case group). Subsequently, analyses of genetic polymorphisms of FBLN5 were performed using the Restriction Fragment Length Polymorphism (RFLP) technique.

RESULTS: A total of 292 women were included in the study. Pregnancy, parity and vaginal delivery in the patients, as well as in data described in the literature, were related to the occurrence of POP in the univariate analysis. However, after binary logistic regression, home birth and age remained independent risk factors for POP. We found no association between the FBLN5 polymorphism and the occurrence of POP $(p=0.371)$.

CONCLUSION: There was no association between the FBLN5 polymorphism and the occurrence of POP in Brazilian women.

KEYWORDS: Female urogenital diseases. Pelvic organ prolapse. Extracellular matrix proteins.

\section{INTRODUCTION}

Pelvic organ prolapse (POP) is a very prevalent disease in our population'. The absolute majority of women who suffer from this disease do not seek medical care for their symptoms². Although POP is a disease without mortality, the morbidity is high, mainly in relation to the decrease in the quality of life of patients's'.

POP results from defects of the pelvic support system, whose main components are the urogenital

DATE OF SUBMISSION: 23-Nov-2019

DATE OF ACCEPTANCE: 08-Dec-2019

CORRESPONDING AUTHOR: Emerson de Oliveira

Av. Lauro Gomes, 2000, Vila Sacadura Cabral, Santo André, SP, Brasil - 09060-870

Tel: + $55114993-5400$

E-mail: emerson_oliveira@terra.com.br 
muscles, vaginal fascia and connective tissue. Several risk factors have already been clearly related to the disease, of which the most well established are parity, previous pregnancies, vaginal and/or instrumentalized births and age $\mathrm{e}^{2,3}$.

Currently, in the field of medical science, we are looking for predictive factors for the development of diseases so that we can act preventively. The study of gene polymorphisms in POP has suggested the possibility of screening young women who are candidates for the development of the disease, thus allowing them to take certain actions throughout their life to minimize the occurrence of POP over time ${ }^{4-6}$.

Gene polymorphisms consist of genetic differences between individuals with no pathological consequences. They arise from genetic variations in a portion of the population according to a given characteristic. These variations become a polymorphism when they have a prevalence of at least $1 \%$ of the population. They may occur in several characteristics of the population, for example, different blood types ${ }^{\mathbf{5}, \mathbf{6}}$.

Polymorphisms of collagen metabolizing genes and extracellular matrix proteins linked to elastogenesis may be related to $\mathrm{POP}^{4,7}$. The extracellular matrix consists of a set of intercellular elements comprised of collagen, proteoglycans, glycoproteins and integrins secreted by the cells that permeate it. The extracellular matrix is responsible for the interaction between cells through the connections between cellular elements ${ }^{8}$.

The synthesis of collagen fibers (comprised of collagen) is a complex and not yet fully understood process. Elastin monomers are secreted by fibroblasts and smooth muscle cells. Microfibrils form the framework where elastin is deposited on the edge of the growing fiber regulated by the enzyme lysyl oxidase (LOX).

Fibulin 5 is a crucial protein for elastogenesis ${ }^{9,10}$. The extracellular matrix of the fibulin 5 protein promotes adhesion between endothelial cells through integrins. The gene encoding this protein is located on chromosome $14 q 32^{11}$. The fibulin 5 protein is encoded by the FBLN5 gene and promotes endothelial cell adhesion. Mutations of fibulin 5 are related to degenerative diseases and $\mathrm{POP}^{8,10}$.

This study evaluated the gene polymorphism of the Fibulin 5 fraction snp1, as well as its risk factors, to establish a correlation with the occurrence of POPs through the Restriction Fragment Length Polymorphism (RFLP) technique.

\section{METHODS}

Study design

This is a single-center prospective cohort study carried out between 2014 and 2016 of patients who were admitted to the Urogynecology and Vaginal Surgery Section of the Department of Obstetrics and Gynecology of the Faculdade de Medicina do ABC (FMABC) in Santo André, São Paulo, Brasil. The study observed the ethical guidelines of the Brazilian Health Council and followed the principles of the Declaration of Helsinki. The study was previously evaluated and approved by the Research Ethics Committee from FMABC (process number 554.670/2014). All patients were informed about the study and signed a consent form to participate.

\section{Patients}

Women with a clinical history compatible with post menopause (no menses for at least one year) were included. POP was determined through gynecological exam, following the classification proposed by the International Continence Society (ICS), American Society of Urogynecology (ASUG) and the Society of Gynecologic Surgeons (SGS) ${ }^{12}$ (Figures 1, 2 and 3). Women with clinical diagnoses of stages III and IV of prolapse were included in the case group. The control group was comprised of women with prolapse stages 0 or I. The criteria for non-inclusion were refusal of blood collection and a history of prior vaginal surgery of any kind.

Weight and height were measured to calculate body mass index (BMI). Sociodemographic and clinical data (family history of genital dystopia, obstetric history, age at menopause, previous use of hormone therapy, constipation history, chronic cough and chronic diseases) were collected by a physician interview.

\section{DNA extraction}

Blood samples were collected with EDTA and centrifuged. A leukocyte-rich fraction was transferred to a new tube and stored at $-20^{\circ} \mathrm{C}\left(-4^{\circ} \mathrm{F}\right)$. Genomic DNA was extracted from leukocytes using an illustra blood genomicPrep Mini spin kit (GE Healthcare), following the instructions from the supplier. DNA preparation was quantified by UV absorbance using a NanoVue Plus spectrophotometer (GE Healthcare).

Genetic analysis of polymorphism rs12586948

Amplification of the FBLN5 gene promoter including the polymorphism (rs 12586948) was conducted in a $10 \mu \mathrm{L}$ reaction using approximately 100 
ng of genomic DNA, PCR Master Mix (Promega) and primers described by Khadzhieva et al. ${ }^{11}: \mathrm{R}$ (5'-TACCTGAATGGAAGCCCTTG-3') and F (5'GCAGAATCTCAGGgCTAGGA-3'). The PCR protocol started with an initial stage of $94^{\circ} \mathrm{C}\left(201^{\circ} \mathrm{F}\right)$ for $5 \mathrm{~min}$, followed by 45 cycles at three temperatures $\left(94^{\circ} \mathrm{C} / 201^{\circ} \mathrm{F}\right.$ for $30 \mathrm{~s}, 55^{\circ} \mathrm{C} / 131^{\circ} \mathrm{F}$ for $60 \mathrm{~s}$, and $72^{\circ} \mathrm{C} / 162^{\circ} \mathrm{C}$ for $60 \mathrm{~s}$ ) and a final incubation at $37^{\circ} \mathrm{C} / 97^{\circ} \mathrm{F}$ for $16 \mathrm{~h}$. The amplified DNA was digested with an AluI restriction enzyme (Biolabs) and analyzed with 3.0\% agarose electrophoresis. Genotypes were set by the observed pattern of digestion bands: a single band of $238 \mathrm{bp}$ for homozygous GG, two bands of $238 \mathrm{bp}$ and $196 \mathrm{bp}$ and a single band of $196 \mathrm{bp}$ for homozygous AA; the bands of $37 \mathrm{bp}$ and $42 \mathrm{bp}$ were not visible (Figure 1).

\section{Statistical Analysis}

An unpaired t-test was used to compare quantitative variables. The Shapiro-Wilk test was performed to obtain the normality of the quantitative data. Chisquare and Fisher's exact tests compared the qualitative variables. Data analysis was carried out using GraphPad Prism 6 and SPSS version 23. Odd ratios (ORs) were used to estimate, after stratification of the groups, the influence of clinical characteristics

\section{FIGURE 1}

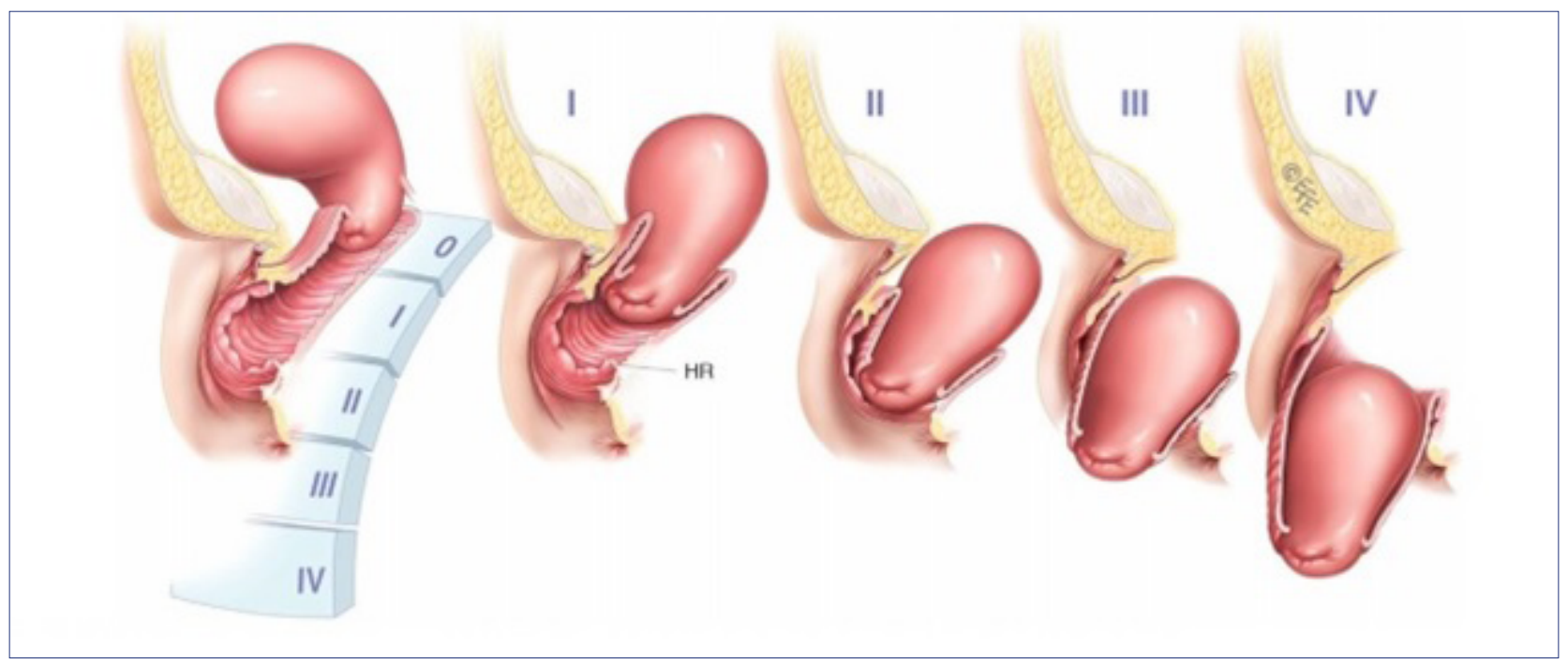

FIGURE 2

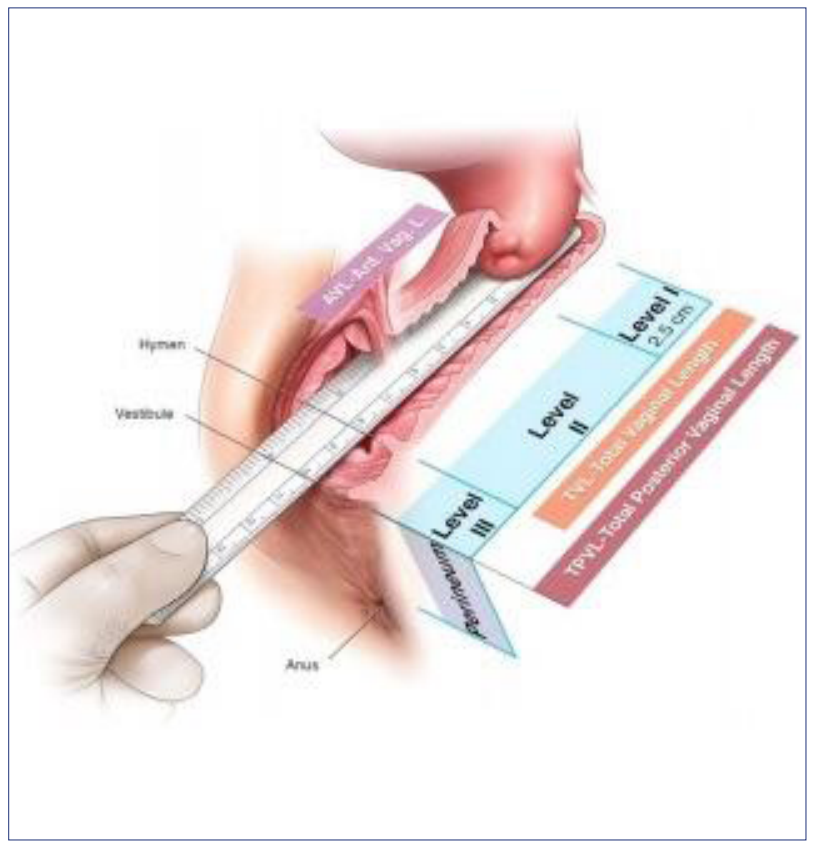

FIGURE 3

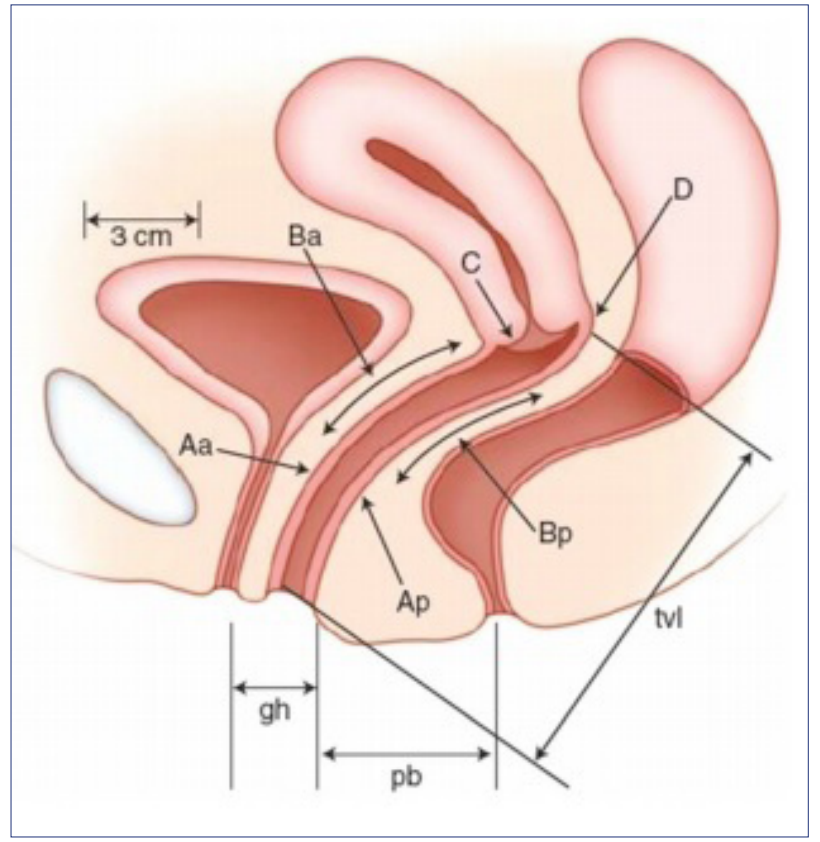


on the risk of POP, obtained from the binary logistic regression model. The assumed confidence interval was $95 \%$ (95\% CDI), and the assumed significance level was $5 \%(p<0.05)$.

\section{RESULTS}

The study included 292 women with a mean age of 68.4 years in the case group and 57.8 years in the control group, with a statistically significant difference between the groups. Overall, the women were mostly Caucasian and had similar BMIs. Pregancy, parity and vaginal delivery of the patients, as well as those reported in the literature, were related to the occurrence of POP in the univariate analysis (Table 1). However, after binary logistic regression, home birth and age remained independent risk factors for POP occurrence (Table 2).

Hardy-Weinberg equilibrium was not observed between the groups ( $p=0.01)$, and we found the following genotypes: 125 GG homozygotes, with 55 in the case group and 70 in the control group; and 74 with at least one $\mathrm{A}(\mathrm{AG}+\mathrm{AA})$, with 27 in the case group and 47 in the control group. There was no significant difference in the presence of genotypes between cases and controls $(p=0.371)$ (Table 3$)$.

TABLE 1. INCIDENCE OF RISK FACTORS FOR PELVIC ORGAN PROLAPSE

\begin{tabular}{l|l|l|l}
\hline Variables & $\begin{array}{l}\text { Case }(\mathrm{n}=112) \\
\mathrm{N}, \text { mean or } \%\end{array}$ & $\begin{array}{l}\text { Control }(\mathrm{n}=180) \\
\mathrm{N}, \text { mean or } \%\end{array}$ & $\mathrm{P}$ \\
\hline Age & 68.4 & 57.8 & $<0.0001$ \\
\hline Caucasian & $69.9 \%$ & $64.8 \%$ & 0.422 \\
\hline Non-Caucasian & $30.1 \%$ & $35.2 \%$ & 0.874 \\
\hline BMI & 28.8 & 28.9 & 0.07 \\
\hline Age of menopause & 48.8 & 46.6 & 0.09 \\
\hline Use of hormone replacement therapy & $10.7 \%$ & $18.1 \%$ & 0.15 \\
\hline Smoking & $13.1 \%$ & $20.1 \%$ & 0.186 \\
\hline Arterial hypertension & $57.8 \%$ & $49.4 \%$ & 0.888 \\
\hline Diabetes mellitus & $24.5 \%$ & $23.7 \%$ & 0.889 \\
\hline Dyslipidemia & $25.4 \%$ & $24.7 \%$ & 0.08 \\
\hline Chronic cough & $1.8 \%$ & $6.8 \%$ & 0.35 \\
\hline Constipation & $14.3 \%$ & $10.4 \%$ & $<0.0001$ \\
\hline Pregnancy & 5.6 & 3.5 & $<0.0001$ \\
\hline Parity & 4.8 & 2.9 & $<0.0001$ \\
\hline Vaginal deliver & 4.1 & 2.3 & 0.377 \\
\hline Cesarian birth & 0.08 & 0.12 & 0.147 \\
\hline Weight of heaviest newborn & 3516 & 3059 & $>0.999$ \\
\hline Episiotomy & $8.3 \%$ & $9.2 \%$ & 0.768 \\
\hline Labor analgesia & $3.7 \%$ & $4.8 \%$ & $<0.0001$ \\
\hline Home birth & $25,9 \%$ & $3.05 \%$ & $>0.999$ \\
\hline Previous hysterectomy & $15.2 \%$ & $15.6 \%$ & 0.077 \\
\hline Activities with great effort & $22.5 \%$ & $14.1 \%$ & 5 \\
\hline Stistica & & \\
\hline
\end{tabular}

Statistical test for values expressed as the mean: Student's t-te st; Statistical test for values expressed as percentages: Fisher's exact test; Statistical test for values expressed as the mean: Student's t-te st; Statistical test for values expressed as percentages: Fisher's exact test; Statistical Analysis with Student's T-Test or Fisher's Exact, as appropriate.

TABLE 2. MULTIVARIATE ANALYSIS WITH BINARY LOGISTIC REGRESSION OF POTENTIAL RISK FACTORS FOR POP

\begin{tabular}{l|l|l|l|l} 
Covariable & $\begin{array}{l}\text { Gross OR } \\
\text { Cl }\end{array}$ & $P$ & $\begin{array}{l}\text { Adjusted OR } \\
\text { Cl }\end{array}$ & $P$ \\
\hline Age $\geq 51$ & $15.57(4.73-51.2)$ & $<0.0001$ & $11.89(3.53-40)$ & $<0.0001$ \\
\hline Pregnancies $\geq 3$ & $2.02(1.24-3.28)$ & 0.004 & $0.656(0.283-1.51)$ & 0.325 \\
\hline Vaginal birth $\geq 3$ & $3.12(1.86-5.23)$ & $<0.0001$ & $1.91(0.7-5.22)$ & 0.202 \\
\hline Parity $\geq 3$ & $2.64(1.62-4.31)$ & $<0.0001$ & $2.01(0.665-6.1)$ & 0.216 \\
\hline Home birth & $11.1(4.14-29.7)$ & $<0.0001$ & $9.645(3.35-27.7)$ & $<0.0001$ \\
\hline
\end{tabular}

OR: Odds ratio; Cl: Confidence Interval. 
TABLE 3. GENOTYPIC OCCURRENCE BETWEEN CASES AND CONTROLS

\begin{tabular}{l|l|l|l} 
Genotype & Case & Control & P \\
\hline$G G$ & 55 & 27 & 0.371 \\
\hline$A A+A G$ & 70 & 47 & \\
\hline
\end{tabular}

Statistical Analysis: Fisher's exact test

\section{FIGURE ???}

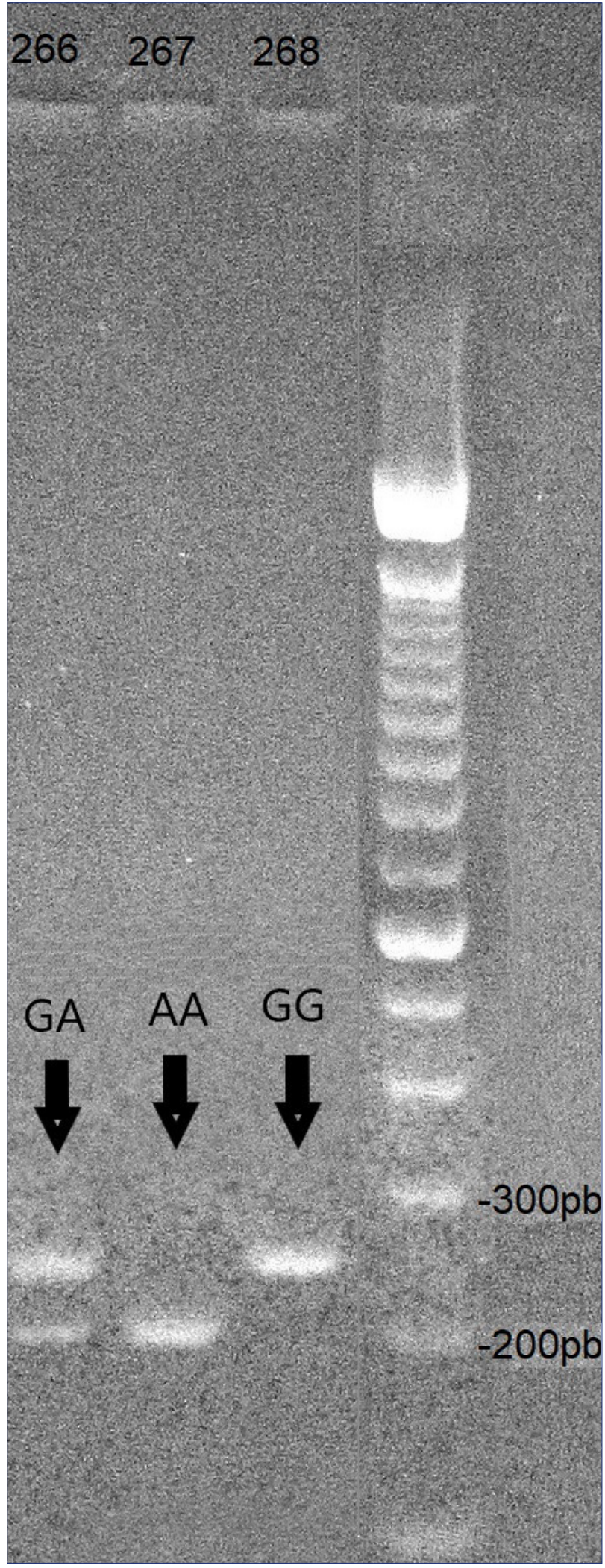

\section{DISCUSSION}

The study of polymorphisms is being developed in several diseases, including neoplasic ones. The possibility of identifying predictive factors for disease prevention strongly impacts treatment costs and can prevent disease in susceptible individuals.

Our group has been studying the impact of these polymorphisms on prolapse of pelvic organs and is being one of the pioneers in this line of research in Brasil. In many parts of the world, this same line is yielding a database that may help provide predictors for disease development. In Brasil, there are some groups with POP research studying the prevalence, impact and risk factors related to this disease.

Several studies around the world study the gene polymorphisms of collagen metabolization of different populations and different results are observed. Khadzhieva et al. ${ }^{11}$ suggested that 4 of 11 fibulin 5 polymorphisms studied were related to POP, however the rs 12586948 were not correlated. The study of this group served as a basis for ours and thus we sought to assess whether the premise found by these authors also applied in our population. Therefore, we use the SNP RFLP method as the most common and reproducible polymorphism according to the study mentioned above ${ }^{13}$.

Some studies suggest that decreasing fibulin protein expression 5 increases the risk of POP. Zhao and Zhou ${ }^{1}$ detected a decrease or absence of fibulin 5 expression in uterosacral ligaments of women with POP. Choi et al. ${ }^{14}$ analyzed the role of protein fibulin 5 in elastogenesis and concluded that it plays an important role in the quality of the genesis of elastic fiber. In line with the last two studies, Wieslander et al. ${ }^{15}$ demonstrated that the absence of fibulin 5 in the vaginal wall of rats compromises the elastogenesis and increases local protease, related to the occurrence of POP. Also corroborated with these findings, the group by Söderberg et al. ${ }^{16}$ which observed a lower expression of fibrin 5 mRNA in individuals with POP and the de Jung et al. ${ }^{17}$ who observed a lower expression of fibulin 5 in hysterectomized patients with POP and concluded that the deficiency of this protein is an important factor in the genesis of the disease. Drewes et al. ${ }^{18}$ inferred that postpartum remodeling of collagen depends on a balance between fiber synthesis and fiber degradation.

Thus, genetic defects that make fiber remodeling difficult can lead to POP in some women and thus justifies the interest of several researchers in the 
line of research we have been working on. In Brasil, our study is pioneering and we found no association between polymorphism rs 12586948 and POP, ratifying Khadzieva et al. ${ }^{11}$. In addition, the risk factors for POP described in the literature were also evidenced in our study, as related and independent variables, such as home birth and age. The important factor is the heterogeneity of the Asian population compared to the Brazilian one. Therefore, the important miscegenation in our population and all the diversity that is peculiar to it may have made it difficult to point out factors in our study.

There is currently a growing discussion regarding birth methods in our society. Caesarean birth, so frequent in Brasil, has been restrained, either by the alarming number, either by the attempt to prioritize vaginal delivery, considered natural. The "Obstetric violence", a term coined suggesting the violation of parturient rights has been used as a focus for prioritizing vaginal delivery. The humanization of childbirth, a fact sought by all involved (whether the healthcare professional or patient) has in many cases been confused with the defense of home birth.

Given this situation, and because we observe a correlation of the increased risk of genital prolapse in patients with this polymorphism, this leads us to rethink about the thoughtless defense of vaginal delivery, especially home delivery. It is suggested that women with other types of polymorphisms may increase the chance of genital prolapse when undergoing home birth, as observed in the possibility of selection by the professional and the patient's method of delivery, given the risk associated with the presence of polymorphism. Despite the limitations, this study is important because it is the first in Brasil investigating and trying to demonstrate a relationship between Fibulin 5 polymorphism and POP, and it will certainly contribute to future meta-analyzes. Also, we believe it is necessary to increase the sample so that we can respond more safely to the question that motivated us in this study.

In conclusion, our data did not demonstrate any association between the Fibulin 5 polymorphism and POP occurrence but found a correlation between the risk factors as describe in the literature.

\section{Acknowledgements}

The authors thank FAPESP (Fundação de Amparo à Pesquisa do Estado de São Paulo) for financially supporting this research under contract 2014/01107-6.

\section{Author Contributions}

Marcus Vinicius Barbosa de Paula - main author, contribute to concept, investigation, research, methodology, analysis and writing the article; Marcos Antônio de Farias Lira Júnior - contribute to research, methodology, analysis and writing the article; Vivian Costa e Silva Crocco Monteiro - contribute to research, methodology analysis and writing the article; Ricardo Peres Souto - contribute to concept, supervision, methodology, analysis and editing the article; César Eduardo Fernandes - contribute to concept, formal analysis, methodology, project administration, supervision; Emerson de Oliveira - contribute to concept, research, supervision, methodology, analysis and editing the article.

\section{RESUMO}

OBJETIVOS: O prolapso de órgãos pélvicos (POP) é uma situação muito frequente em nossa população que pode levar a uma diminuição significativa da qualidade de vida dos pacientes. Atualmente, buscam-se fatores preditivos para o desenvolvimento de POPs e, assim, este estudo correlaciona um polimorfismo de Fibulina 5 (FBLN5) com a ocorrência da doença.

MÉTODOS: Estudo de coorte com mulheres na pós-menopausa, divididas por grupos pelos estádios 0 e I do POP (grupo controle) e POP III e IV (grupo caso). Posteriormente, análises do polimorfismo genético de FBLN5 foram realizadas utilizando a técnica de Polimorfismo de Comprimento de Fragmentos de Restrição (RFLP).

RESULTADOS: Um total de 292 mulheres foi incluído no estudo. Gestação, paridade e parto vaginal, como bem descritos na literatura, foram relacionados à ocorrência de POPs na análise univariada. No entanto, após a regressão logística binária, o parto domiciliar e a idade permaneceram como fatores de risco independentes para os POPS. Não encontramos associação deste polimorfismo FBLN5 com a ocorrência de POP $(p=0,371)$.

CONCLUSÃo: Não houve associação deste polimorfismo FBLN5 com a ocorrência de POPs em mulheres brasileiras.

PALAVRAS-CHAVE: Doenças urogenitais femininas. Prolapso de órgão pélvico. Proteínas da matriz extracelular. 


\section{REFERENCES}

1. Zhao BH, Zhou JH. Decreased expression of elastin, fibulin -5 and lysyl oxidase -like 1 in the uterosacral ligaments of postmenopausal women with pelvic organ prolapse. J Obstet Gynaecol Res. 2012;38(6):925-31.

2. Olsen AL, Smith VJ, Bergstrom JO, Colling JC, Clark AL. Epidemiology of surgically managed pelvic organ prolapse and urinary incontinence. Obstet Gynecol. 1997;89(4):501-6.

3. Jelovsek JE, Maher C, Barber MD. Pelvic organ prolapse. Lancet. 2007;369(9566):1027-38

4. Chin K, Wieslander C, Shi H, Balgobin S, Montoya TI, Yanagisawa H, et al. Pelvic organ support in animals with partial loss of fibulin-5 in the vaginal wall. PLoS One. 2016;11(4):e0152793.

5. Botstein D, White RL, Skolnick M, Davis RW. Construction of a genetic linkage map in man using restriction fragment length polymorphisms. Am J Hum Genet. 1980;32(3):314-31.

6. Risch N, Merikangas K. The future of genetic studies of complex human diseases. Science. 1996;273(5281):1516-7.

7. Budatha M, Roshanravan S, Zheng Q, Weislander C, Chapman SL, Davis EC, et al. Extracellular matrix proteases contribute to progression of pelvic organ prolapse in mice and humans. J Clin Invest. 2011;121(5):2048-59.

8. Abedin M, King N. Diverse evolutionary paths to cell adhesion. Trends Cell Biol. 2010;20(12):734-42

9. Budatha M, Silva S, Montoya TI, Suzuki A, Shah-Simpson S, Wieslander CK et al. Dysregulation of protease and protease inhibitors in a mouse model of human pelvic organ prolapse. PLoS One. 2013;8(2):e56376.

10. Yanagisawa H, Schluterman MK, Brekken RA. Fibulin-5, an integrin-binding matricellular protein: its function in development and disease. J Cell Commun Signal. 2009;3(3-4):337-47.
11. Khadzhieva MB, Kamoeva SV, Chumachenko AG, Ivanova AV, Volodin IV Vladimirov IS, et al. Fibulin-5 (FBLN5) gene polymorphism is associated with pelvic organ prolapse. Maturitas. 2014;78(4):287-92.

12. Haylen BT, Maher CF, Barber MD, Camargo S, Dandolu V, Digesu A, et al. An International Urogynecological Association (IUGA) / International Continence Society (ICS) joint report on the terminology for female pelvic organ prolapse (POP). Int Urogynecol J. 2016;27(2):165-94.

13. Leaché $A D$, Oaks JR. The utility of single nucleotide polymorphism (SNP) data in phylogenetics. Annu Rev Ecol Evol Syst. 2017;48(1):69-84.

14. Choi J, Bergdahl A, Zheng Q, Starcher B, Yanagisawa H, Davis EC. Analysis of dermal elastic fibers in the absence of fibulin- 5 reveals potential roles for fibulin-5 in elastic fiber assembly. Matrix Biology. 2009;28(4):211-20.

15. Wieslander CK, Rahn DD, McIntire DD, Acevedo IF, Drewes PG, Yanagisawa $\mathrm{H}$, et al. Quantification of pelvic organ prolapse in mice: vaginal protease activity precedes increased MOPQ scores in fibulin 5 knockout mice. Biol Reprod. 2009;80(3):407-14.

16. Söderberg MW, Byström B, Kalamajski S, Malmström A, Ekman-Ordeberg $G$. Gene expressions of small leucine-rich repeat proteoglycans and fibulin-5 are decreased in pelvic organ prolapse. Mol Hum Reprod. 2009;15(4):251-7.

17. Jung HI, leon MI, Yim GW, Kim SK, Choi IR, Bai SW. Changes in expression of fibulin-5 and lysyl oxidase-like 1 associated with pelvic organ prolapse. Eur J Obstet Gynecol Reprod Biol. 2009;145(1):117-22.

18. Drewes PG, Yanagisawa H, Starcher B, Hornstra I, Csiszar K, Marinis SI, et al. Pelvic organ prolapse in fibulin-5 knockout mice: pregnancy-induced changes in elastic fiber homeostasis in mouse vagina. Am J Pathol. 2007;170(2):578-89. 